\title{
Amphibia, Anura, Leptodactylidae, Leptodactylus syphax Bokermann, 1969: Distribution extension and geographic distribution map
}

\author{
Etielle B. Andrade ${ }^{1,2^{*}}$, Rafael Guimarães ${ }^{1,3}$, João Manoel A. Leite $\mathrm{Jr}^{4}$ and José Roberto S. A. Leite ${ }^{1}$ \\ 1 Universidade Federal do Piauí, Campus Ministro Reis Velloso, Núcleo de Pesquisa em Biodiversidade e Biotecnologia, Biotec. CEP 64202-020, \\ Parnaíba, PI, Brazil. \\ 2 Universidade Estadual do Piauí, Campus “Heróis do Jenipapo”. Avenida Santo Antônio S/N, Bairro São Luís. CEP 64280-000. Campo Maior, PI, \\ Brazil. \\ 3 Universidade Federal do Maranhão, Programa de Mestrado em Biodiversidade e Conservação. Av. dos Portugueses, s/n, Campus do Bacanga. CEP \\ 65085-580. Sao Luis, MA, Brasil. \\ 4 Departamento de Polícia Rodoviária Federal - Ministério da Justiça, 19aㅗRPRF/PA 3aDel. BR 230 (Rodovia Transamazônica) Km 109. Marabá, PA, \\ Brazil. \\ * Corresponding author. E-mail: etlandrade@hotmail.com
}

\begin{abstract}
Leptodactylus syphax is a mid-sized frog that inhabits open rocky areas in central, southeastern and northeastern Brazil, besides southern Paraguay and eastern Bolivia. Here we reported an adult male from Parque Municipal Cachoeira do Bota Fora, Piripiri municipality, state of Piauí, northeastern Brazil, expanding the known distribution of Leptodactylus syphax ca. $320 \mathrm{~km}$ northwards.
\end{abstract}

The Neotropical genus Leptodactylus Fitzinger, 1826 includes 88 species, widely distributed in South America (Frost 2010). The genus is divided in five species groups: L. melanonotus, L. latrans, L. fuscus, L. marmoratus, and L. pentadactylus (Heyer 1969; Frost 2010). The L. pentadactylus group comprises formally 19 species (Frost 2010), including Leptodactylus syphax Bokermann, 1969, described from Cuiabá municipality, state of Mato Grosso, central Brazil. This species is a mid-sized frog (males raging from 58-83 $\mathrm{mm}$ and females $70-90 \mathrm{~mm} \mathrm{SVL}$ ) that inhabits open areas associated to rocky outcrop in central, southeastern and northeastern Brazil, besides southern Paraguay and eastern Bolivia, between elevations of 175 $\mathrm{m}$ to $1500 \mathrm{~m}$ (Heyer et al. 2010).

During fieldwork at Parque Municipal Cachoeira do Bota Fora $\left(04^{\circ} 12^{\prime} 00^{\prime \prime} \mathrm{S}, 41^{\circ} 39^{\prime} 60^{\prime \prime} \mathrm{W}\right)$, located at
Piripiri municipality, north region of state of Piauí, on 12 December 2007, an individual of L. syphax was recorded. The Parque Municipal Cachoeira do Bota Fora is covered by dense forest habitat, and correspond to a transition region between Cerrado, Caatinga and Tropical Rainforest (Barroso and Guimarães 1980; Oliveira and Martins 2007). Several lentic water bodies are formed during the rainy season, and are used for reproduction of several amphibian species.

The adult male of L. syphax (SVL $=73.3 \mathrm{~mm}$ ) was collected vocalizing at rocky shores of a small stream. The individual had hypertrophied arms, chest and thumb spines (Figure 1). These characteristics are typical of sexually active male of $L$. pentadactylus species group (Heyer 2005). Previous records of the species at state of Piauí were made in the cities of São Raimundo Nonato
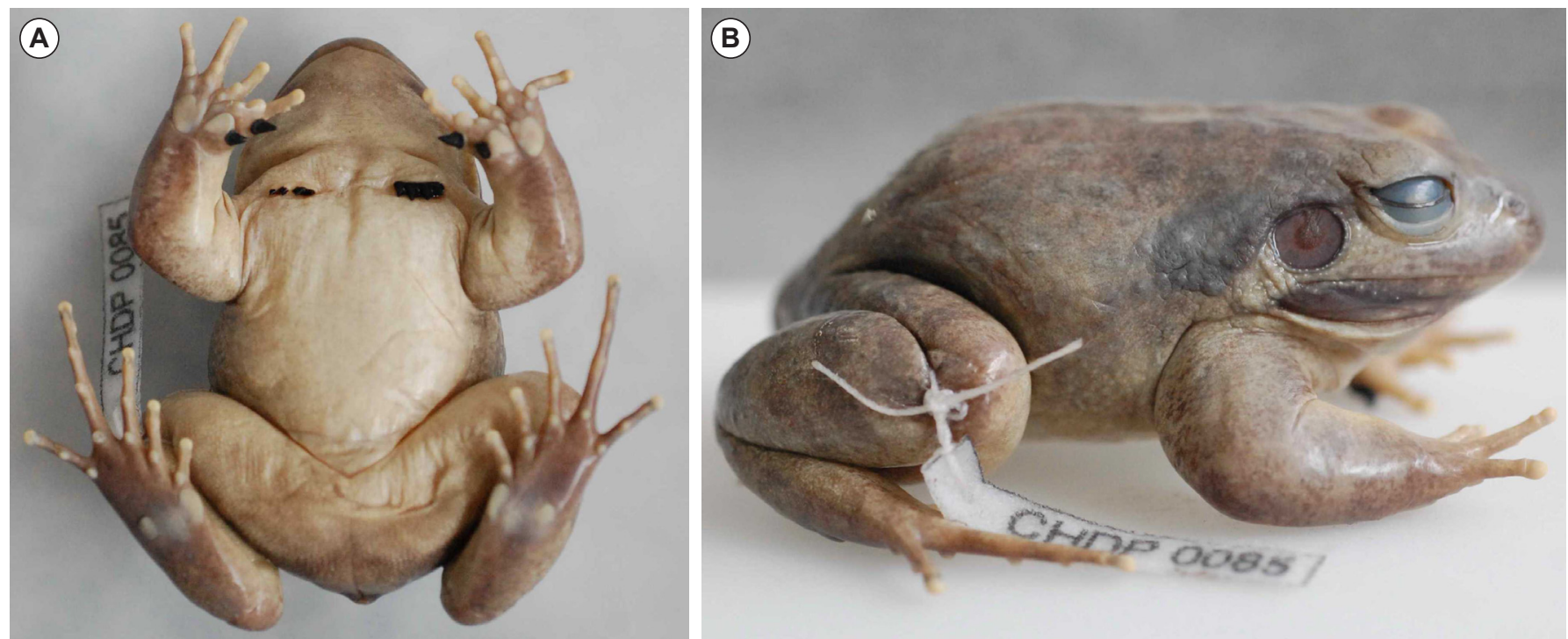

FIGURE 1. Leptodactylus syphax from Parque Municipal Cachoeira do Bota Fora, Piripiri municipality, state of Piauí, northeastern Brazil. A - Ventral view showing the chest and thumb spines. B - Lateral view showing hypertrophied arms. SVL $=73.3 \mathrm{~mm}$. 
(Cardoso and Heyer 1995) and Floriano (Lima and Cruz, unpublished data). These records were done in south and center regions of state of Piauí, in habitats similar to found in Parque Municipal Cachoeira do Bota Fora (Figure 2). This new record extends the geographic distribution of L. syphax ca. $320 \mathrm{~km}$ northeastern straight-line from the previous records at from Floriano municipality, in the state of Piauí. The specimen collected was deposited at Coleção Herpetológica Delta do Parnaíba - CHDP, Universidade Federal do Piauí - CMRV/UFPI, Parnaíba
- Piauí, under number CHDP 0085 (License 17727-1/09 IBAMA/RAM).

The knowledge about amphibian fauna of northern Piauí still remains scarce, although information about this subject have become available in recent years (e.g. Annunziata et al. 2007; Silva et al. 2007; Loebmann and Mai 2008; Leite Jr. et al. 2008; Loebmann et al. 2010, Benício et al. 2011). These records demonstrate the great need of inventories to better characterize the amphibian fauna of the state of Piauí.

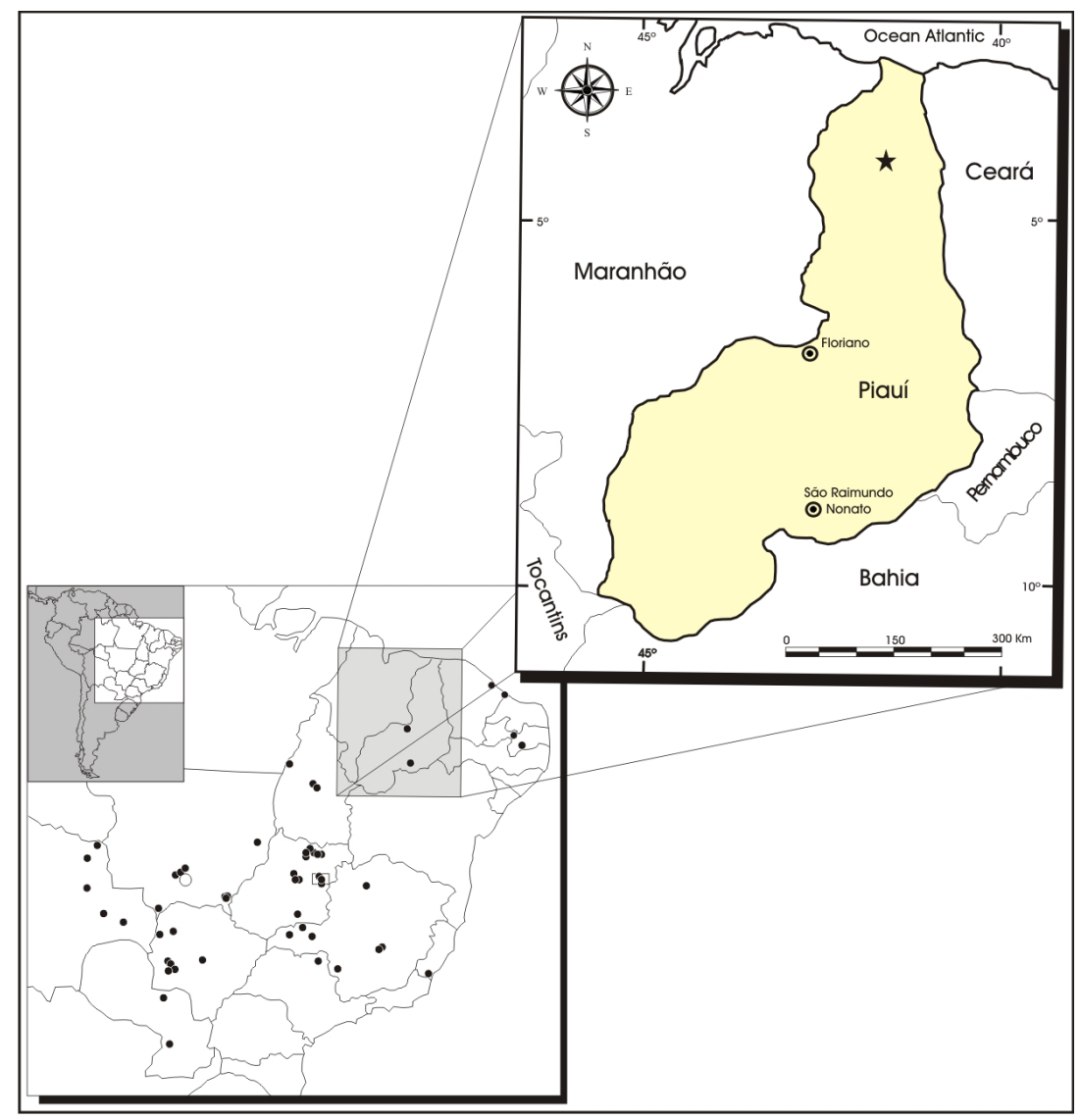

FIGURE 2. Geographic distribution of Leptodactylus syphax. White circle indicate the type-locality (Cuiabá, Mato Grosso) and black point represent actual distributions (see Heyer et al. 2010). Black star represent the new record for the species, municipality of Piripiri, state of Piauí.

ACKNowledgments: We thank Washington L. S. Vieira (UFPB) for confirmation of the species identity and Reuber Brandão (UnB) and Cristina Arzabe (Embrapa Meio-Norte) for very useful comments on the manuscript. Luiza I. Lima, Allane Maria V. Ribeiro, Laise B. C. Silva, Sherelyn N. G and Pedro C. Silva for participation in fieldworks. Financial support was provided by CNPq Universal 480997/2007-1/ Edital MCT/ CNPq 15/2007.

\section{Literature Cited}

Annunziata, B.B., W.M. Fontenele, I.S. Castro, R.F. Gurgel and K.A. Nascimento. 2007. Amphibia, Anura, Hylidae, Dendropsophus rubicundulus: Distribution extension. Check List 3(3): 242-243.

Barroso, G.M. and E.F, Guimarães. 1980. Excursão botânica ao Parque Nacional de Sete Cidades, Piauí. Rodriguésia 32: 241-267.

Benício, R.A., G.R. Silva and M.G. Fonseca. 2011. Amphibia, Anura, Hylidae, Sphaenorhynchus lacteus (Daudin, 1800): First record of the genus and species for the state of Piauí, Brazil. Check List 7(2): 196-197.

Bokermann, W.C.A. 1969. Uma nova espécie de Leptodactylus de Mato Grosso (Anura, Leptodactylidae). Revista Brasileira de Biologia 29: 13-16.

Cardoso, A.J. and W.R. Heyer. 1995. Advertisement, aggressive, and possible seismic signals of the frog Leptodactylus syphax (Amphibia, Leptodactylidae). Alytes 13: 67-76.

Frost, D.R. 2010. Amphibian Species of the World: an Online Reference. Version 5.4 (8 April, 2010). Electronic database accessible at http:// research.amnh.org/vz/herpetology/amphibia/index.php. American Museum of Natural History, New York, USA. Captured on 19 August 2010.
Heyer, W.R. 1969. The adaptive ecology of the species group of the genus Leptodactylus (Amphibia, Leptodactylidae). Evolution 23: 421-428.

Heyer, W.R. 2005. Variation and taxonomic clarification of the large species of the Leptodactylus pentadactylus species group (Amphibian: Leptodactylidae) from Middle America, Northern South America, and Amazonia. Arquivo de Zoologia, São Paulo 37(3): 269-348.

Heyer, W.R., W.W. Heyer and R.O. de Sá. 2010. Leptodactylus syphax. Catalogue of American Amphibians and Reptiles 868: 1-9.

Leite Jr., J.M.A., J.M.S. Sampaio, R.R. Silva-Leite, L.F. Toledo, D. Loebmann; J.R.S.A. Leite. 2008. Amphibia, Anura, Hylidae, Scinax fuscomarginatus: distribution extension. Check List 4(4): 475-477.

Loebmann, D. and A.C.G. Mai. 2008. Amphibia, Anura, Coastal Zone, Piauí state, Northeastern Brazil. Check List 4(2): 161-170.

Oliveira, M.E.A. and F.R. Martins. 2007. Mapeamento, florística e estrutura da transição campo floresta na vegetação (cerrado) do Parque Nacional de Sete Cidades, Nordeste do Brasil. Tecnologia \& Desenvolvimento Sustentável 3: 108-132.

Silva, G.R., M.R. Alves, C.L. Santos, S.D.V. Souza and B.B. Annunziata. 2007. Anfíbios das Dunas litorâneas do extremo norte do Estado do Piauí, Brasil. Sitientibus. Série Ciências Biológicas 7(4): 334-340.

RECEIVED: January 2011

LAST REVISED: June 2011

ACCEPTED: June 2011

Published ONLINE: September 2011

EDITORIAL RESPONSIBILITY: Juliana Zina 